\title{
EFFECT OF AQUEOUS FOLIAR SPRAY OF LEAF EXTRACTS OF SOME PLANT SPECIES OF ASTERACEAE ON RUST DISEASE INCIDENCE \% OF GROUNDNUT.
}

\author{
S.D. Kadlag1, B.N. Zaware ${ }^{2}$, S.N. Varpe $^{1}$ and R.G. Khose ${ }^{3}$ \\ 1. Nutan Arts, Commerce and Science College Rajapur Tal. Sangamner \\ (422605) Dist. Ahmednagar (MS); \\ 2. Principal: Mamasaheb Mohol College Kothrud, Pune (MS). \\ 3. Ex-HOD Post Graduate of Botany, New Arts, Commerce and Science \\ College Ahmednagar (MS). \\ kadlagsubhash@gmail.com
}

Communicated: 13.03 .21

Revision : 19.04.21 \& 9.05.2021

Accepted: 19.05 .2021

Published: 30.05.2021

\begin{abstract}
:
Rust (Puccinia arachidis Speg) of ground nut has become one of the serious diseases in India since 1971. It gets spread rapidly through seed/pods contamination; wind borne uredospores. In severe infection condition the crop is completely destroyed. It can be controlled by using rust resistant groundnut varieties and by using chemicals. Farmers have been using synthetic chemicals indiscriminately causing environmental pollution and poisoning nature and food. It is not desirable. This pathogen survives in the plant debris in soil and easily.Rust appears in the field under warm and humid conditions. We tried to investigate fungicidaleffect of fresh leaf extracts of ten species of Asteraceae family against phytopathogenic fungi that cause crop plant diseases. According to the Rust disease incidence \%, control of the disease could be put in an order of: Pluchea tomentosa > Erigeron bonariensis $>$ Synedrella nodiflora $>$ Parthenium hysterophorus $>$ Launaea procumbens $>$ Tagetes erecta $>$ Tridax procumbens $>$ Sphagneticola calandulacea $>$ Cynathillium cinereum $>$ mixed $>$ Eclipta prostrata
\end{abstract}

Keywords: Plant spp. Of Asteraceae family, rust disease of Groundnut, antifungal.

\section{INTRODUCTION:}

Allelopathy is defined as "Chemically elicited interactions among plants mediated by varieties of chemical compounds with different of modes of biochemical actions." Molisch (1937) introduced the word "Allelopathy" for beneficial as well as harmful (detrimental) reciprocal biochemical interactions among plants including microorganisms. Allelochemicals are the natural secondary metabolites produced by the plants.

With the increase in human population demand for basic needs went on increasing. To meet the demands agricultural techniques, synthetic toxic biocides and synthetic fertilizers have been used to increase the agricultural yields.
Indiscriminate use of these and water resulted in soil and water pollution. Our fertile lands have become non-fertile. Increasing global awareness towards environmental pollution problems has led research workers to find out safe alternatives.

Plants produce varieties of allelochemicals as natural secondary metabolites. These can be used as biocides that are eco-friendly i.e. biodegradable, renewable and abundantly available. There is a vast scope for research in investigating allelochemicals and use them in sustainable agriculture for food production without polluting environment Plants contain varieties of chemicals that are produced as secondary metabolites. They are natural and 
easily biodegraded. Since botanical source of biocides is eco-friendly i.e. biodegradable, renewable and abundantly available, there is a vast scope for research in Allelopathy and investigating allelochemicals and use them in agriculture without polluting environment. The present paper deals with the aspects of fungicidal potentials of weeds of Asteraceae family.

\section{REVIEW OF LITERATURE:}

Govindasamy and Balasubramanian (1989) worked on biological control of groundnut disease by usingTrichoderma harzianumthat reduced germination \% of uredospores.Govindaswamy (1989) c.f. Rice (1994) worked on controlling 'rust' in Arachis hypogea caused by Puccinia arachidis. Pretreatment peanuts with conidia of Trichoderma harzianum inhibited germination and germ tube growth of the rust uredospores.

Kishore and Pande (2005) recorded those extracts of Tagetes patula, Cymopsis teragolobus significantly inhibited the germination of spores of Puccinia personata and $P$. arachidis.

Riaz et al (2007) conducted experiments to assess effects of leaf residues of plants viz. Parthenium hysterophorus L., Ageratum conyzoides L. on mycorrhizal colonization and corm rot disease of Gladiolus caused by Fusarium oxysporum f.sp.gladioli (Massey) Snyd. and Hans.

Martyniuk and Bialy (2008) worked on antifungal activity of eight saponins obtained from Medicago arabica. Saponins 'hederagenin' with two sugars (glucose and arabinose) had higher antifungal effect than 'hederagenin' with one sugar arabinose. Saponins were inhibitory to Aspergillus Niger, Fusarium oxysporum, Pythium aphanidermatum and Sclerotium rolfsii. Faizi et al (2008) worked antifungal as well as antibacterial activities of Tagetes patula. They isolated flavonoid patuletin which in minimum inhibitory concentration (MIC) inhibited growth of Staphylococcus spp., Streptococcus spp., Micrococcus spp. bacteria. Petroleum ether extract of roots inhibited the fungus Candida albicans.

Arslan et al (2009) evaluated antifungal activity of extracts of spices against bean rust caused by Uromyces appendiculatus. Extracts of Basil, black cumin, black paper, fennel, laurel, parsley, celery and rosemary were tested against the fungal pathogen. Fungicidal activity against bean rust was in an order of: Black cumin (Nigella sativa L.) > laurel > Basil > Celery
$>$ black paper $>$ rosemary $>$ fennel $>$ parsley. Rust control efficacy in percentage of Black cumin $(85 \%)$ was higher while that of Parsley $(5.9 \%)$ was least.

Arora and Kaushik (2003) recorded that the extracts of Conyzabon ariensis (L.) Crong and Erigeron karvinskianus DC. (Family Asteraceae) were highly fungicidal against soybean fungal pathogens viz., Colletotrichum truncatum (Schwein) Andrus \& Moore, Fusarium oxysporum Schl. ex Fr. and Macrophomina phaseolina (Tassi) Goid.

Chuihua et al. (2004) found out that Ageratum conyzoides L., (Asteraceae family) contains allelopathins like 3-caryophyllene, p-bisabolene and $\mathrm{p}$-farnescene that could exert synergistic inhibitory effect on test plants. It is herbicidal as well as fungicidal.

Patil and Kamble (2015) recorded that leaf extracts of Eupatorium odoratum, Blumea balsminifera, Cassia tora L, Vitex negundo, Xanthium indicum and Hyptis suaveolens inhibited spore germination of Puccinia arachidis Speg.

\section{MATERIAL AND METHOD:}

Study area: Ahmednagar district is the largest district of Maharashtra state. It is located between $188^{\circ}$ 'and $75^{\circ} 5^{\prime}$ North latitude and 7009'and 7505'East longitude. The Sahyadri has formed a naturally boundaries in between Ahmednagar, Thane and Nasik District. Balaghat is the prominent ranges of Sahydri that traverse the district. Plant species were identified by using Flora of Maharashtra, Almeida (2001).

Groundnut 'HB11' variety of Mahadhan Pvt. Ltd. company, Indore (India) was sown in the field in Shendi village near Ahmednagar city in the month of April 2018. Spraying of extracts was started 30 DAS (days after sowing). 40\% leaf extracts of ten selected plant species of Asteraceae were prepared. $40 \%$ mixture of all leaf extracts was also prepared. Spraying was done in the morning regularly from 30 to 70 DAS.Control plants were sprayed with pure water. Readings were taken, tabulated and disease incidence \%, rust incidence \% were calculated (Table 1 and Graph 1).

\section{RESULTS AND DISCUSSION:}

Cynathillium cinereum (L.) H.Rob. reduced rust disease incidence \% from 11.82 to 1.98 i.e. by $9.84 \%$. 
Sphagneticola calandulacea (L.) Pruskireduced the rust disease incidence \% from 14.98 to 5.53 i.e. by $9.45 \%$.

Erigeron bonariensis Linn.reduced the rust disease incidence from \% 9.64to 3.06 i.e. by $6.58 \%$.

Launaea procumbens (Roxb.) Ramayya \& Rajgopalreduced the rust disease incidence \% from 12.32 to 4.43 i.e. by $7.89 \%$.

Tridax procumbens (L.) L reduced the rust disease incidence \% from 11.39 to 2.82 i.e. by $8.57 \%$.

Pluchea tomentosaDC reduced the rust disease incidence $\%$ from 13.11 to 8.90 i.e. by $4.21 \%$.

Tagetes erecta Lreduced the rust disease incidence \% from 11.00 to 2.82 i.e. by $8.18 \%$.

Parthenium hysterophorusL reduced the rust disease incidence \% from 12.54 to 4.76 i.e. by $7.78 \%$.

Synedrella nodiflora(Linn.) Gaertn. reduced the rust disease incidence \% from 13.50 to 1.98 i.e. by $6.97 \%$.

Eclipta prostrata.(Linn.) L reduced the rust disease incidence \% from 16.67 to 1.49 i.e. by $15.18 \%$.

Effect of mixed extracts of ten plants rust disease incidence \% : When sprayed on the ground nut crop 30Days to 70Daysperiod three times per week mixed leafextracts reduced the rust disease incidence \% 13.15 to 0.23 i.e. by $12.9 \%$.

'Rust disease incidence \%' of the disease by plant species was in an order of: Eclipta prostrata $>$ mixed $>$ Cynathillium cinereum $>$ Sphagneticola calandulacea > Tridax procumbens $>$ Tagetes erecta $>$ Launaea procumbens $>$ Parthenium hysterophorus $>$ Synedrella nodiflora $>$ Erigeron bonariensis >Pluchea tomentosa (Table 1, Graph 1). More reduction in disease incidence by Eclipta prostrata and less by Pluchea tomentosa.

For controlling rust,tikka and other fungal diseases of groundnut (Arachis hypogea L.), one of valuable commodity of the crops grown for seeds, oil and fodder crop, synthetic fungicides like Aprop,Bumper, Orius, Plethora, Benamain and Mainex are being used by the farmers. To save poisoning and deteriorating soil, underground water by using hazardous non-biodegradable synthetic fungicides, it is desirable to control fungal diseases using natural, easily biodegradable plant originated fungicides. Compositae (Asteraceae) is a cosmopolitan family.It is one of the dominant families of flowering plants. Majority grow in wild nature. They are easily available. Many workers have been doing research on the species to find out their efficacy of biocidal (fungicide /insecticide / nematicide etc.) nature.

\section{ACKNOWLEDGEMENT:}

I express my sincere sense of gratitude to my research guide Dr. Zaware B. N. and Co-guide Dr. Khose R.G. former Head of the Botany Department for their keen interest in the subject, scholarly inspiration, efficient guidance, constant encouragement and pertinent criticism during the course of present investigations, which always kept my research work in progress.

I should not miss this opportunity to express my heart -felt gratitude and regards to the Hon. Management of Pragatik Shikshan Sanstha Rajapur Tal. Sangamner Dist. Ahmednagar and Principal Dr. B.H. Zaware, Principal Dr. Matkar Ahmednagar.

\section{REFERENCES:}

Almeida,M.R. (1998) Flora of Maharashtra vol I to V.Orient press Mumbai (India)

Arora Charu and Kaushik R.D. (2003) Fungicidal activity of plant extracts from Uttaranchal hills against soybean fungal pathogens. Allelopathy Journal 11 (2): 217-228.

Arslan, U.; Ilhan, K. and Karabulut, O. A. (2009) Antifungal activity of aqueous extracts of spices against bean rust (Uromyces appendiculatus) Allelopathy Journal 24 (1): 207-214.

Chuihua Kong, Fei Hu, Wenju Liang, Wang Peng and Yong Jiang (2004) Allelopathic potential of Ageratum conyzoides at various growth 
I J R B A T, Issue (IX), Vol. II, May 2021: 236-240

A Double-Blind Peer Reviewed \& Refereed Journal

stages in different habitats. Allelopathy Journal 13 (2): 233-240.

Faizi, S.; Siddiqi, H.; Bano, S.; Naz, A.; Lubna; Mazhar, K.; Nasim, S.; Riaz, T.; Kamal, S.; Ahmad, A. and Khan S.A. (2008) Antibacterial and antifungal activities of different parts of Tagetes patula: Preparation of Patuletin derivatives. Pharmaceutical biologyhttps:// doi.org 46(5):309-320.

Govindasamy, V. and Balasubramanian, R. (1989) Biological control of groundnut rust (Puccinia arachidis) by Trichoderma harzianum. Zeitschrift Pflanzenkransh pflanzenshutz 96:337-45. In Rice, E.L. (1994)Biological control of selected plant diseases by microorganisms. Allelopathy Journal 1 (2): 77-88.http:/ / www.zbmed.de.

Kishore,G.K. and Pande Suresh (2005) Integrated management of late leaf spot and rust

disease of groundnut (Arachis hypogeal.) with Prosopis juliflora leaf extracts and vjlorothalonil. J.of Pest management 51(4); 325-332.

Martyniuk, S. and Bialy, Z.(2008) Antifungal activity of various saponins from Medicago arabica Allelopathy Journal 21 (2): 411-418.

Molish,H.(1937) Der Einflusseiner Pflanze auf die andere-Allelopathie. Jena Germany: Gustav Fischer In Willis, R.J. (1994) Terminology and trends in allelopathy. Allelopathy Journal1 (1): 6-28.

Patil, B.J and Kamble S.K. (2015) Inhibitory effect of leaf extracts on spore germination of Puccinia arachidis Speg. J. Microb. World 17 (1): 27-31.

Riaz, T.; Khan, S.N. and Javaid, A. (2007) Effect of incorporation of allelopathic plants leaf residues on mycorrhizal colonization and Gladiolus diseases. Allelopathy Journal 20 (1): 61-70.

Rice, E.L.(1994)Biological control of selected plant diseases by microorganisms. Allelopathy Journal 1 (2): 77-88. 
Table No 1: Effect of foliar spray of leaf extracts of Asteraceae plants on Rust disease incidence $\%$ of groundnut.

\begin{tabular}{|c|c|c|c|c|c|}
\hline $\begin{array}{c}\text { Spraying extract of plant } \\
\text { species }\end{array}$ & 30DAYS & 40DAYS & 50DAYS & 6ODAYS & 7ODAYS \\
\hline Control No spraying & 26.55 & 25.68 & 17.97 & 14.69 & 16.37 \\
\hline Pluchea tomentosa DC. & 13.11 & 12.6 & 12.48 & 9.63 & 8.9 \\
\hline $\begin{array}{l}\text { Synedrella nodiflora } \\
\text { (Linn.)Gaertn. }\end{array}$ & 13.5 & 11.45 & 11.72 & 8.45 & 6.53 \\
\hline Erigeron bonariensis Linn. & 9.64 & 8.13 & 5.37 & 4.01 & 3.06 \\
\hline $\begin{array}{l}\text { Cyanthillium cinereum } \\
\text { (L.)H.Rob. }\end{array}$ & 11.82 & 1023 & 10 & 7.26 & 1.98 \\
\hline Parthenium hysterophorus L. & 12.54 & 9.91 & 8.73 & 5.56 & 4.76 \\
\hline $\begin{array}{l}\text { Sphagneticola calendulacea } \\
\text { (L.)Pruski. }\end{array}$ & 14.98 & 10.57 & 10.5 & 6.7 & 5.53 \\
\hline Mixed spray & 13.15 & 13.39 & 2.95 & 0.65 & 0.23 \\
\hline $\begin{array}{l}\text { Launaea procumbens } \\
\text { (Roxb.)Ramayya \& Rajgopal. }\end{array}$ & 12.32 & 11.94 & 11.64 & 8.29 & 4.43 \\
\hline Tagetes erecta L. & 11 & 10.69 & 5.81 & 3.14 & 2.82 \\
\hline Tridax procumbens (L.)L. & 11.39 & 10.24 & 4.84 & 3.86 & 2.82 \\
\hline Eclipta prostrata (Linn.)L. & 16.67 & 15.18 & 12.04 & 5.15 & 1.49 \\
\hline
\end{tabular}

Graph-1: Effect of leaf extracts of plant species of Asteraceae on rust incidence \% 


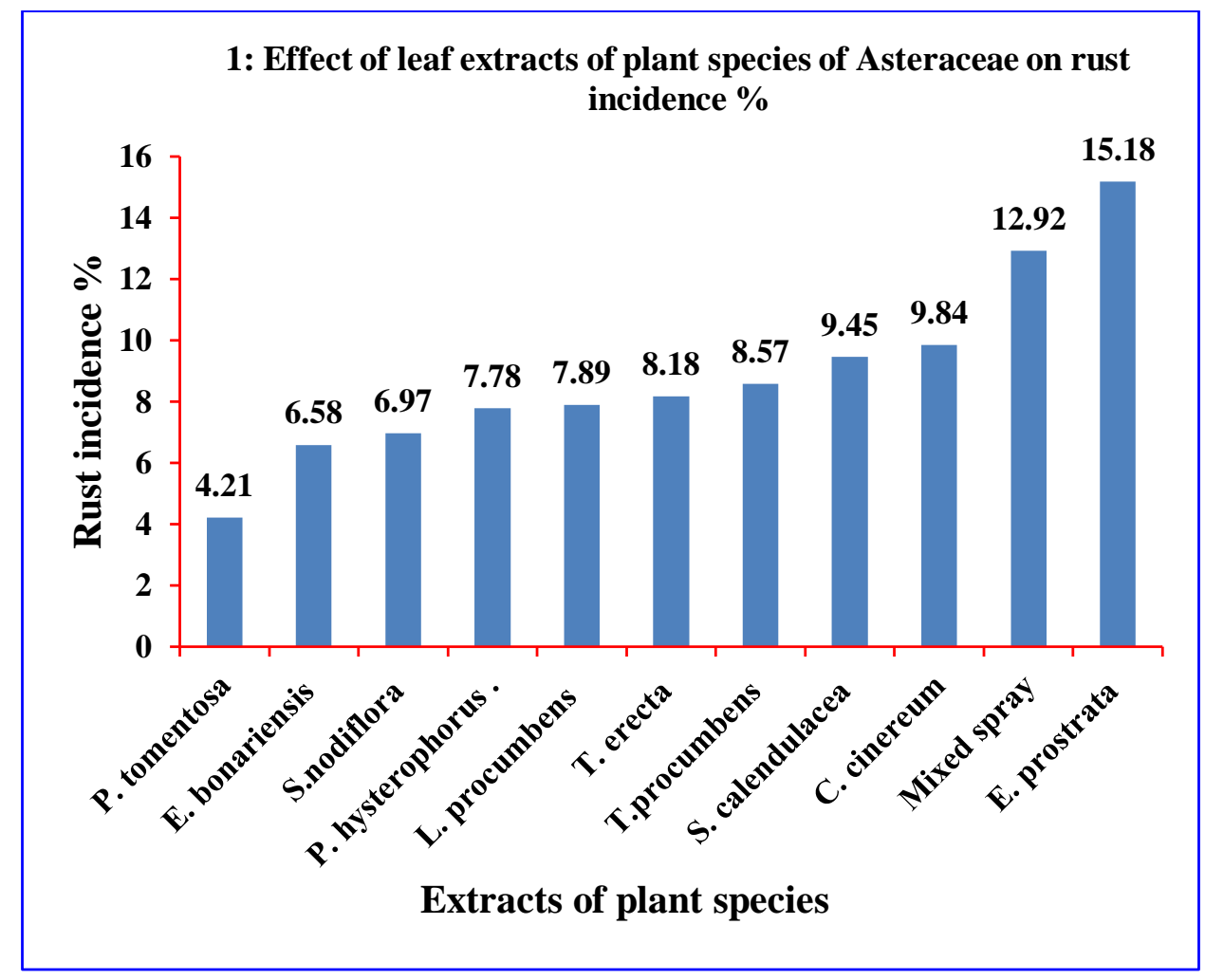

